\title{
A Rare Case of Thoracic Subdural Hematoma after Recovery from Dengue Fever
}

Sir,

Dengue hemorrhagic fever can present with serious neurological manifestation consequent to coagulation disorders including thrombocytopenia and can involve any organ of the body. ${ }^{[1]}$ Thrombocytopenia can affect the neuroaxis secondary to vascular leakage ${ }^{[2]}$ Here, we report a rare case of dengue fever with dorsal spinal subdural hematoma.

A female patient of 54 years presented with the history of short febrile illness of 4 days with serum hemoglobin of $11.2 \mathrm{~g} / \mathrm{dL}$, a total leukocyte count of $11,400 / \mathrm{mm}^{3}$ and a platelet count $(\mathrm{PC})$ of $60 \times 10^{9} / \mathrm{L}$. In view of an ongoing dengue outbreak, the possibility of dengue fever was considered at this juncture. The patient was hemodynamically stable with a pulse rate of 70 beats $/ \mathrm{min}$ and blood pressure of $112 / 76 \mathrm{mmHg}$. Serum dengue nonstructural protein 1 antigen and dengue-specific IgM antibody came positive. Management ensued based on the existing national guidelines for the management of dengue fever with the emphasis on maintaining the fluid and electrolyte balance and clinical parameter monitoring. ${ }^{[3]}$ Investigations after 2 days showed progressive decrease in PC $\left(20 \times 10^{9} / \mathrm{L}\right)$. The patient was transfused 2 units of single donor platelets (SDPs), and a repeat PC was found to be $70 \times 10^{9} / \mathrm{L}$. On $9^{\text {th }}$ day, she developed low back ache with sudden onset of bilateral lower limb numbness and paresthesia. This was associated with inability to get up from the lying position/inability to walk and progressed further to complete paraplegia over 6-12 h.

Magnetic resonance imaging (MRI) of the spine revealed a subdural hematoma with severe cord compression at T6-T12 level [Figure 1a and b]. MRI of the brain was

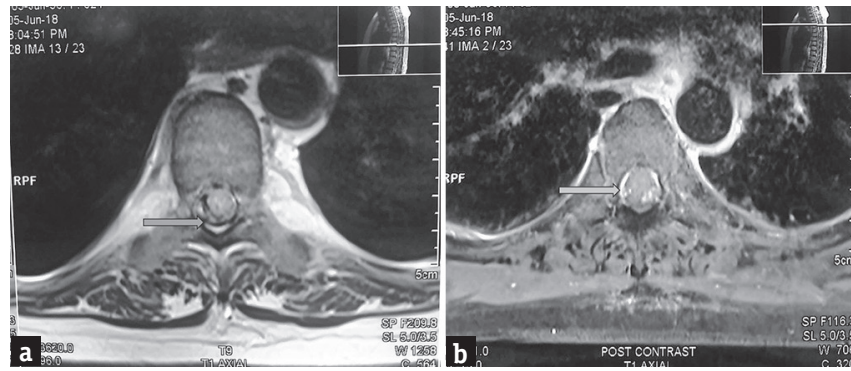

Figure 1: (a) Precontrast magnetic resonance imaging dorsal spine axial section showing area of hypointensity within the subdural space. (b) postcontrast images showing heterogenous enhancement within the subdural space on T1 axial sequence indicating hemorrhage/blood degradation products

normal. Her coagulation parameters were within normal limits. The patient underwent T6-T12 laminectomy for the evacuation of subdural hematoma. Intraoperative blood loss was about $2.0 \mathrm{~L}$, and she was transfused four units of packed red blood cell and two units of SDP. Motor power improved postoperatively from $1 / 5$ to $2 / 5$ and was discharged on the $21^{\text {st }}$ day of illness.

Dengue fever presentation can vary from a self-limiting course to a hemorrhagic manifestation leading finally to a fatal condition with multiple organ failure, i.e., dengue shock syndrome (DSS). ${ }^{[1]}$ CNS involvement in dengue fever has the incidence of less than $1 \%$ which may include encephalopathy, intracranial hemorrhages (subdural and subarachnoid), encephalitis ${ }^{[4,5]}$ Central diabetes insipidus with diffuse cerebral hemorrhages with no evidence of thrombocytopenia, has been reported. ${ }^{[1]}$

Cord ischemia and myelitis can lead to acute rapidly progressive quadriplegia caused by epidural hematoma 
resulting in cord compression at the dorsal level. ${ }^{[4]}$ Presentation of paraplegia due to neuraxial involvement resulting from a hemorrhagic complication may be delayed, as was observed in our case. Mahale et al. reported a similar case when their patient following recovery from DSS presented with delayed intracranial subdural hematoma. ${ }^{[5]}$

DHF involving the CNS can have a varied manifestation which warrants every clinician to be vigilant in diagnosis and management so as to prevent life-threatening morbidity and mortality.

\section{Acknowledgment}

The authors would like to thank Dr. Amit Bajpai, MD Radiodiagnosis for explaining the MRI report.

\section{Financial support and sponsorship}

Nil.

\section{Conflicts of interest}

There are no conflicts of interest.

\section{Shalendra Singh, Deepak Dwivedi ${ }^{1}$, Navdeep Sethi,} Debashish Paul

Department of Anaesthesia and Critical Care, Armed Forces Medical College, ${ }^{1}$ Department of Anaesthesia and Critical Care, Command Hospital (Southern Command), Armed Forces Medical

College, Pune, Maharashtra, India

Address for correspondence: Dr. Deepak Dwivedi, Department of Anaesthesia and Critical Care, Command Hospital (Southern Command) Armed Forces Medical College,

Pune - 411 040, Maharashtra, India. E-mail: deepakdwivedi739@gmail.com

\section{REFERENCES}

1. Jayasinghe NS, Thalagala E, Wattegama M, Thirumavalavan K. Dengue fever with diffuse cerebral hemorrhages, subdural hematoma and cranial diabetes insipidus. BMC Res Notes 2016;9:265.

2. Wiwanitkit $\mathrm{S}$, Wiwanitkit V. Acute brain hemorrhage in dengue. J Acute Dis 2014;3:240-41.

3. National Guidelines for Clinical Management of Dengue Fever. Country Office for India. World Health Organization; 2015. Available from: http://www.who.int/iris/handle/10665/208893 [Last accessed 2018 Sep 10].

4. Singh M, Garg K, Bisht A, Sharma BS, Singh PK, Pandia M, et al. Spinal epidural hematoma with myelitis and brainstem hemorrhage: An unusual complication of dengue fever. Neurol India 2013;61:541-3.

5. Mahale RR, Mehta A, Shankar AK, Srinivasa R. Delayed subdural hematoma after recovery from dengue shock syndrome. J Neurosci Rural Pract 2016;7:323-4.

This is an open access journal, and articles are distributed under the terms of the Creative Commons Attribution-NonCommercial-ShareAlike 4.0 License, which allows others to remix, tweak, and build upon the work non-commercially, as long as appropriate credit is given and the new creations are licensed under the identical terms.

\begin{tabular}{|c|c|}
\hline \multicolumn{2}{|c|}{ Access this article online } \\
\hline Quick Response Code: & \\
\hline 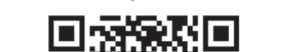 & Website: \\
\hline 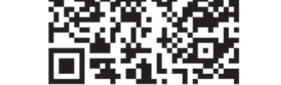 & $\begin{array}{l}\text { DOI: } \\
\text { 10.4103/jnrp.jnrp_314_18 }\end{array}$ \\
\hline
\end{tabular}

How to cite this article: Singh S, Dwivedi D, Sethi N, Paul D. A rare case of thoracic subdural hematoma after recovery from dengue fever. J Neurosci Rural Pract 2019;10:380-1.

(C) 2019 Journal of Neurosciences in Rural Practice | Published by Wolters Kluwer - Medknow 